\title{
Charaka's normative theories of ethics insight from ayurveda
}

\author{
Kalpana Tawalare $^{1 *}$, Kiran Tawalare ${ }^{2}$, Mohan Yende ${ }^{3}$ \\ ${ }^{\mathbf{1}}$ Associate Professor, ${ }^{\mathbf{2}}$ Assistant Professor, ${ }^{3}$ Professor, ${ }^{1,3}$ Dept. of Rachana Sharir, ${ }^{2}$ Dept. of Kriya Sharir, \\ ${ }^{1,3}$ Bhausaheb Mulak Ayurved College \& Hospital, Nagpur, Maharashtra, ${ }^{2}$ Shri Ayurved College, Nagpur, Maharashtra, India
}

*Corresponding Author: Kalpana Tawalare

Email: drkirantawalare@gmail.com

\begin{abstract}
Introduction: Ayurveda is a life science, hence put forth maximum stress on health and its maintenance. Sadavrutta (code of good conduct) has a major capacity in maintaining good health, as it contain the set of rule to be followed by person for maintenance of health. Charaka stated that aarogya (health) and indriyavijay (control over the sense organ) can be achieved by adapting sadavritta in routine life. Similarly to achieve the health, Charaka explain various normative theories of ethics, unfortunately non highlighted till now.

Objectives: Objectives are to put forth the Charaka's the normative theories of ethics and to highlighten the importance of Charka's normative theories, as existing other traditional theories of ethics.

Materials and Methods: Classical texts of Ayurveda viz. bruhatrayee and laghutrayee were studied for literature regarding ethics from Ayurveda, ethical theories from modern science was also collected.

Conclusion: Charaka's theory of dharma (virtue), harsha (contentment), karma (obligations), sadvritta (social conduct), vyavasaay (professional conduct), aacharana (high value care) all these theories of ethics explain moral and ethics about living life up to quite high level as theory of virtue, greatest happiness principle, Kant's principle, ethics of care exist in modern science. These Charaka's theories have importance as good as traditional theories of ethics existing at that time in modern science.
\end{abstract}

Keywords: Ayurveda, Ethics, Sadavrutta, normative theory, Dharma, Harsha.

\section{Introduction}

Ethics has been integral component of medicine since the time of Veda. In Vedic period moral virtues were called as Dharma. It means consider as per duty excellence and to hold the society together for its growth and well being. ${ }^{1}$ In recent time it is closely related with law, human rights. It mainly deals with human being and their life. It prescribe higher standard which helps to medical student to recognized difficult situations and to deal with them in principled manner. According to modern science broadly there are three types of ethical theories consequentiality, non-consequentiality and agent centered. Similarly modern science explains the existence of three traditional theories of ethics metaethics, applied ethics and normative theories. Normative theories in some sense explain what action you should take in particular situation while dealing with patient? It also includes the useful procedure to deliberate the optimal action in given scenario. ${ }^{2}$

Ayurveda is the science by which life is attained. This science put forth maximum stress on good health and its maintenance. Cure needs for diseased person only. ${ }^{3}$ Regarding moral and ethical theories abundant literature is available in modern science, whereas references from Ayurveda not cited though it is explained up to quite good mark whole classic text of Ayurveda, bruhtrayee and laghutrayee. Among these bruhtrayee, Charak samhita is medicinal treatise. Charaka stated that aarogya (health) and indriyavijay (control over the sense organ) can be achieved by adapting sadavritta (code of good conduct). ${ }^{4} \mathrm{He}$ explains trisutra Ayurveda hetu (cause), ling (symptoms) and aushadhi (medicinal treatment) for healthy and diseased person. He does not merely mention the treatment in the form of drugs but gives various normative theories of ethics which directly has impact on body to maintain the health and provide longevity of life. So with an objective to explore the valuable normative theories put forth by Charaka in that period $200 \mathrm{BC}$, study was carried out.

\section{Objective}

To put forth the Charaka's the normative theories of ethics. To highlight the importance of Charaka's normative theories, as existing other traditional theories of ethics.

\section{Materials and Methods}

Classical texts of Ayurveda viz. bruhatrayee and laghutrayee were studied for literature regarding ethics from Ayurveada, ethical theories from modern science was also collected. These references from both streams of knowledge were compared and analyzed critically.

\section{Discussion}

\section{Theory of Dharma (Virtue)}

Good health is the best source to achieve dharma (virtue), artha (wealth), kama (gratification), and moksha (emancipation). ${ }^{4}$ In real sense dharma is vast concept and encloses guidelines to be followed as krudhanamnumata (pacification of anger), bhitanam ashwasayita (consoling) the frightened, deenanaam abhyupatta (helping the poor one), amarshaghna (remover of intolerance), ragdweshhetunaam hanta (capable of destroying causes of anger and jealousy), na anaruta (do not lie), na anyaswamadadid (do not take over others possessions), apaishunya (you should not gossip). ${ }^{5}$ In the same concern modern science explains theory of virtue ethics was put forth by Aristotle around $350 \mathrm{BC}^{6}{ }^{\text {This }}$ theory gives emphasis on cultivation of human virtues like kindness, compassion, honesty. 


\section{Theory Harsha (Contentment)}

Charaka's stated dharmic kriya (Virtual acts) brings forth harsha (happiness) while the contrary ones lead to dukha (sorrow), ${ }^{7}$ it means dharmik kriya is best source to bring happiness and adharmik kriya leads to sorrow. That's why he also stated that physician should treat patient with considering bhutdaya (compassion) and dharma (highest virtue) then he will enjoy the maximum happiness. ${ }^{8}$ This theory of harsha resembles with principle of utility explain by John Stuart mill (1806-1876). The principle of utility also knows as "Greatest happiness principle" according to his theory the goal of morality is to maximize the happiness. Secondly Charaka explain theory of Lok-purush samya siddhant (Commonness in the human being and universe) for internal happiness. He explains that person is equal to the universe. Whatever formed entities are in the universe, the same are in the person and vice versa. ${ }^{9}$ The purpose of describing commonness is achieving true knowledge. On seeing the entire universe in himself one realize the truth that self alone is agent of happiness and misery and none else. $^{10}$

\section{Ethics of Karma (Physician's obligation)}

Charaka says that primary duty of physician is towards their patient. Physician should never think ill of patient even at the cost of his life. ${ }^{11}$ Physician should possess six qualities as vidya (learning), vitarka (rationality), vidnayan (knowledge of science), smruti (memory), tatparta (devotion) and kriya (action). The physician who possesses all these auspicious qualities can showers happiness on patient ${ }^{12}$ Physician should wise learned and active enough to treat the patient with having all equipments So that he can follow his obligations promptly. ${ }^{13}$ In this context Kant in 1724 explain the importance of duty of physician which is known as principle of deontology explains by Kant (17241804). This principle focuses on primary duties of physician and respectful attitude towards the patient's right. Physician must kept duties sincerely and with good intention. ${ }^{14}$

\section{Theory of Sadvritta (social conduct)}

In this regard Charaka says that one should not insult sato (noble person) and guru (preceptors) $\mathrm{Na}$ striyamvajaneet (one should not insult the woman), ${ }^{15}$ One should not be attached to stri (women), mitra (friends) and bhrutya (servants) with sinful conduct ${ }^{16}$ na atisamay jarhiyat (One should not give up the valuable time excessively), na niyam bhindyat (One should not break the established set of rule) One should not have interest in madya (wine), duta (gambling) and veshya (prostitutes). One should not disclose secrete and should not insult anybody. One should not be conceited, unskilled, unfavorite and envious. One should not abuse the old, preceptors, the administrative class and king. One should not speak to much. One should not turn out king, anurakta (person attached), and person who knows secretes. ${ }^{17}$

\section{Theory for Vyavsaaya (professional conduct)}

Don't become impatient neither over exhilarated. One should not confide on all. Should not critical are all times. ${ }^{18}$ na karyakalamatipatayet (one should not postpone things at the time of action), na aparikshitam (nor should one take up anything without examining it). Bhuddhiindriyaatibhar (one should not be submissive to his sense organs nor should one turn his unstable mind round). One should not over burden the sense organ. One should not to much dilatory, one should not act under the emotions of anger or exhilaration; one should not live under continued grief. One should not exhilarate in success and depressed in failure. One should confident of the effect of a cause and as such should always initiate the cause. One should not assume that now nothing is to be done. One should not give up courage. One should not remember his scandals. ${ }^{9}$ The ideal physician should avoid sitting together with women, residing with them. ${ }^{20}$ Wearing white cloths, kalyanabhivyavhaaren (wishing the good for all) and bhandhubhuten (friendly behavior with all living beings), with this compassion students enter in divine profession of medicine. ${ }^{21}$

\section{Theory of Aacharana (High value care)}

Sushrutacharya explain the doctor should take care of his patient as his own son. Patient gives himself up in the doctor's hand and has no misgiving about him. Therefore it is the physician duty to look after him as its own son. The patient may doubt his in relative, his son and even his parents, but he has full faith in the physician. ${ }^{22}$ Verginiya Held put forth the theory of ethics of care which was feminist approach to ethics and explains the values of emotions, as Sushruta.

\section{Conclusion}

Charaka's theory of dharma (virtue), harsha (contentment), karma (obligations), sadvritta (social conduct), vyavasaay (professional conduct), aacharana (high value care) all these theories of ethics explain moral and ethics about living life up to quite high level as theory of virtue, greatest happiness principle, Kant's principle, ethics of care exist in modern science. These Charaka's theories have importance as good as traditional theories of ethics existing at that time in modern science.

\section{Conflict of interest}

Authors declare that there is a no conflict of interest.

\section{References}

1. Venimadhav Shastri, Narayan Hari Joshi, Ayurvediy Shabdakosha, Pratham Khand, $\mathrm{I}^{\text {st }}$ edition, Mumbai: Tarktirth Lakshamanshastri Joshi;1968. p. 729.

2. Tom L. Beauchamp Georgetown, Norman E. Bowie, Denis G. Arnold. Ethical Theory and Business. $8^{\text {th }}$ Edition, Prentice Hall, Pearson Education International.

3. Agnivesha, Charaka, Dridhabala, Charak samhita, Sutra Sthana, Arthedashmahamuliya Adhyay, 30/26, edited by Priyavrat Sharma, reprint, Chaukhambha orientalia, Varanasi, 2011.

4. Ibidem (3), Sutra Sthana, Dirghajivitiya Adhyay, 1/26;5.

5. Ibidem (3), Sutra Sthana, Indriyopakramaniya Adhyay, 8/18;54. 
6. https://study.com/academy/lesson/aristotles-virtue-ethicsdefinition-theory.html Ancient Greece Study Guide / History Courses. Aristotle's Virtue Ethics: Definition \& Theory.

Chapter 8. [last seen on 01/11/2019].

7. Ibidem (3), Sharir Sthana, Atulyagotriysharir Adhyay, 2/41;417.

8. Ibidem (3), Chikitsa Sthana, Rasayanadhyaya Adhyay, ayurvedsamutthaniya rasayanpad, 1/4/62;34.

9. Ibidem (3), Sharir Sthana, Purushvichaya Adhyay, 5/3;440.

10. Ibidem (3), Sharir Sthana, Purushvichaya Adhyay, 5/7;440.

11. Ibidem (3), Viman Sthana, Rogbhishagjitiya Adhyay, 8/16;356.

12. Ibidem (3), Sutra Sthana, Indriyopakramaniya Adhyay, 8/23;59.

13. Ibidem (3), Sutra Sthana, Chikitsaprabutiya Adhyay, 16/3;175.

14. Tawalare KA, Nanote KD, Gawai VU, Gotmare AY.

Contribution of Ayurveda in foundation of basic tenets of bioethics. AYU 2014;35(4):366-370. doi: 10.4103/09748520.158982 .

15. Ibidem (3), Sutra Sthana, Indriyopakramaniya Adhyay, 8/22;59.

16. Ibidem (3), Sutra Sthana, Indriyopakramaniya Adhyay, 8/19;59.

17. Ibidem (3), Sutra Sthana, Indriyopakramaniya Adhyay, $8 / 25 ; 60$.

18. Ibidem (3), Sutra Sthana, Indriyopakramaniya Adhyay, $8 / 26 ; 60$.

19. Ibidem (3), Sutra Sthana, Indriyopakramaniya Adhyay, 8/27;61.

20. Chandrat, Nagarjuna, Sushruta samhita, Sutra Sthana, Vishikhanupraveshaniya Adhyaya, 10/9, translated by Prof. K. R. Srikantha Murthy, Volume 1, Chaukhamba Orientalia, Varanasi, 2008;62.

21. Ibidem (20), Sutra Sthana, Vishikhanupraveshaniya Adhyaya, 10/3;59.

22. Ibidem (20), Sutra Sthana, Pranashta shalya vignyaniya Adhyaya, $26 / 3 ; 189$. 